Hanna Serkowska

Katedra Italianistyki, Uniwersytet Warszawski

\title{
Jam recenzent, nie policjant. Z perspektywy recenzenta przekładów współczesnej włoskiej literatury w Polsce po 2000 roku
}

Niniejszą garść uwag wokół włoskiej literatury współczesnej dostępnej w polskim przekładzie podporządkowuję spostrzeżeniu, że do niedawna tak różne między sobą rynki przekładów, jak polski i zachodnioeuropejskie miały okazję nieco się do siebie zbliżyć, zwłaszcza za sprawą czynników rynkowych. Zamierzeniem moim jest naszkicowanie inwentarza tekstów przekładanych na język polski i za ich pośrednictwem naświetlenie zjawisk typowych dla polskiego rynku przekładów ostatnich dwóch dekad (pod wpływem wskazanych zjawisk rynek ten stał się częścią rynku globalnego) oraz wskazanie kilku specyficznych fenomenów, które obserwujemy w sposób szczególnie nasilony w Polsce (na Zachodzie ich przebieg jest odmienny). Dostępne mi obserwatorium łączy zainteresowania zawodowe filologa obcego, pełniącego funkcję pośrednika między kulturą obcą i rodzimą, z doświadczeniem recenzenta włoskich przekładów miesięcznika „Nowe Książki”.

1 Do grona recenzentów włoskich przekładów miesięcznika „Nowe Książki” należeli także: Henryk Bereza, Witold Billip, Cezary Rowiński, Marcin Czerwiński, Jerzy R. Krzyżanowski, Jerzy Adamski, Wacław Sadkowski, Wojciech Żukrowski, Joanna Ugniewska, Halina Kralowa. 
W tej skrótowej prezentacji dwóch dekad przekładów włoskich w Polsce na plan pierwszy wysuwają się wybory przekładowe i polityka wydawnicza, którą te wybory uzasadniają. Pomijane są natomiast badania nad szeroko pojętą recepcją. Decyzje powyższe, uzależnione także od ram, w których ma się pomieścić niniejsza wypowiedź, są pochodną wiary w siłę przebicia i zdolność długiego oddziaływania na odbiorców niepodatnej na tzw. sukces odmiany literatury. Istotne jest również przekonanie, że krytycy/recenzenci, choć nie mają wpływu na decyzje wydawców, to w umiarkowanym stopniu wciąż potrafią jednak ukierunkowywać czytelnicze wybory i odbiory.

\section{Rezydualne możliwości outsiderów}

Początki zainteresowania krytyką literacką wynikały z potrzeby ustanowienia relacji z czytelnikiem. Dziś widzimy, że kontakt ów można nawiązać bez uciążliwego pośrednictwa. Nie obowiązuje już rola policjantów w literaturze, jaką przed laty wyznaczał recenzentom Novalis. Internet radykalnie poszerza krąg odbiorców poprzez lansowanie coraz to nowszych wcieleń masowego recenzenta we wszechobecnych blogach i czasopismach dostępnych online. Także tradycyjna krytyka literacka oddała pole blogującym pisarzom, rekomendującym teksty kolegów i własne. Czytelnicy, zamiast czytać koturnowe roztrząsania zawodowych krytyków, tych nieznośnych arbitrów stylu i elegancji, wysyłają własne rozważania do czasopism, publikowane później w działach „Twoja najlepsza recenzja” czy „Czytelnicy polecają”. Krytycy/recenzenci nie potrafią (już) inspirować decyzji wydawniczych, nie są trendsetterami i nie mają bezpośredniego wpływu na wzrost czytelnictwa. Winę za taki stan rzeczy ponoszą autorzy recenzji sponsorowanych, a komercjalizacja recenzji² prowadzi z kolei do dewaluacji postaci krytyka-eksczam, powstał blisko sto lat temu: „Recenzenci omawiający książki również nie czują żadnego oparcia u swych czytelników. Od dawna już ci ostatni nie interesują się opinią recenzenta, często nikomu nieznanego młodzieńca. Jeżeli mowa o książkach naukowych i esejach, czytelnicy najchętniej widzieliby po prostu szczegółowy spis treści recenzowanej książki, rezerwując dla siebie ostateczny 
perta. Ci ostatni mogą jednak w pewnym stopniu ukierunkowywać lekturę, oddziaływać na wiedzę i wrażliwość odbiorców. Krytyka, z jej nieodłącznymi sądami wartościującymi jako wyznacznikami walorów nie tylko estetycznych, jest wciąż niezbędną aktywnością kulturalną i intelektualną. Krytyk, choć nikogo nie oświeca, może wskazywać drogę czytelnikom błądzącym po internetowych i blurbowych bezdrożach. Aby dobrze pełnić swoją funkcję, powinien być wyposażony w bagaż wiedzy historyczno-literackiej, sprawnie poruszać się po kanonie literackim, orientować $\mathrm{w}$ dawnych i nowszych trendach i zjawiskach. Tak właśnie postrzegam swoją misję: pełnić funkcję recenzenta z sumiennością krytyka, nie rozbierając jednak dzieła na czynniki pierwsze - jak to ma w zwyczaju krytyka akademicka - i nie tonąc w otchłani odniesień (zarazem jednak nie ograniczać pracy do streszczenia recenzowanego tekstu i do wydania sądu wartościującego). Etos recenzenta być może uległ przewartościowaniu, jednak on sam nie powinien kapitulować wobec wolnorynkowej zasady równości gustów.

Są też plusy sytuacji, w której krytyk/recenzent nie ma gwarantowanego mandatu u producentów i u konsumentów dóbr kulturalnych: paradoksalnie daje mu to większą swobodę. Może ponownie aspirować do roli arbitra. $\mathrm{Z}$ tą różnicą, że dziś nazwie siebie raczej ekologiem literatury ${ }^{3}$. A jaka jest stawka w przekładowej grze? Nie chodzi bowiem o sam - skądinąd ważny - wizerunek

sąd o zasłudze i przydatności dla nich danej książki. Tam, gdzie spis rozdziałów nie wystarcza, czytelnik oczekuje od recenzenta krótkiej informacji pozwalającej na sklasyfikowanie książki, dającej pojęcie, do czego dana książka jest podobna. Sprowadzona przez niewdzięcznych czytelników do tych skromnych proporcji, pozbawiona polotu i ambicji recenzja - zwłaszcza w dziale literatury pięknej zaledwie utrzymuje się przy życiu. Ten stan rzeczy jest wynikiem wzrostu produkcji książek oraz zróżnicowania i niecierpliwości czytelników. Wielu z nich najchętniej zastąpiłoby recenzenta przez jakiś mechaniczny proceder streszczający książki. Almanachy ogłaszane przez wielkie firmy wydawnicze i zawierające po kilka stronic $\mathrm{z}$ książek wydanych $\mathrm{w}$ ostatnim sezonie są próbą zastąpienia recenzenta przez mechaniczny proceder drukarski" [Stempowski 1938].

W duchu „ekologii literatury” wypowiada się Giulio Ferroni [2010] w eseju pt. Scritture a perdere. La letteratura negli anni zero. Nawołuje do powstrzymania nadmiernego przyrostu dzieł - pisać należy mniej, lecz lepiej - które zrzekają się jakiejkolwiek funkcji, oddają prym mediom, chylą głowę przed komunikacyjną próżnią, niskim rejestrem językowym i poziomem życia społecznego. 
Włochów i Italii. Pod wpływem włoskich przekładów (ustępujących, rzecz jasna, pola produkcjom filmowym ${ }^{4}$ kształtuje się także nasza ogólna wiedza na temat kultury, literatury, historii Italii (która wpływa również na postrzeganie kraju i jego mieszkańców) - i nie tylko.

\section{Rzut oka na polski rynek przekładów 1945-1989}

Popularność przekładów dzieł obcych pisarzy podlega wielu czynnikom, takim jak: wymiana kulturalna, syntonia klimatu politycznego w obu krajach (lub jej brak), relacje między wydawcami, związki między autorami, wybory i osobiste rekomendacje tłumaczy, popularność pisarzy w ojczyźnie. Do tego dochodzi jeszcze szereg czynników nieprzewidywalnych i działanie przypadku. Nieprzesadzona wydaje się uwaga, że w Polsce, podobnie jak przed 1989 rokiem, współcześnie (choć z przyczyn odmiennych niż kiedyś) rynek wydawniczy żyje życiem odrębnym, niepodporządkowanym oczekiwaniom i upodobaniom czytelników, na gusty i poglądy czytelnicze wszelako aktywnie oddziaływa. Najczęściej gusty te spłaszcza i uniformizuje, a jako jedyne kryterium przyjmuje popularność książki mierzoną liczbą sprzedanych egzemplarzy. Dodajmy, że obecnie ośrodkiem władzy są media społecznościowe. One budują nastroje społeczne, tworzą opinie, wpływają na decyzje (także wyborcze). Odwrotnie więc niż dawniej zyski polityczne wspieranych ugrupowań przekładają się na korzyści rynkowe grup interesów. Terenem tej walki jest, jak niegdyś, kultura. Przyjrzyjmy się teraz kilku zjawiskom, które zwróciły moją uwagę jako charakdziś kino niż teksty, w tym te, które posłużyły jako punkt wyjścia do ekranizacji. Przykładów jest bez liku. Polscy odbiorcy mogą zapoznać się z mechanizmami psychologicznymi, politycznymi i rynkowymi, które wykorzystuje (bądź generuje) włoska kamorra dzięki przekładom książek Roberta Saviana, lecz zdecydowanie szersze grono „zna” Gomorrę z filmu Mattea Garrona, a zwłaszcza z serialu (powstał też serial na podstawie ZeroZeroZero). Obecnie seriale (w ogóle i ten w szczególności) jeszcze silniej oddziaływają na odbiorców niż film. Poza granicami Italii wywierają wpływ na odbiór Włoch i przyciągają rzesze turystów do Neapolu, a w samych Włoszech lansują serialową modę i pewien rodzaj postaci. 
terystyczne dla polskiego rynku przekładów włoskiej literatury współczesnejs.

Zanim przejdziemy jednak do prezentacji stanu z ostatnich lat, przyda się krótki rzut oka na sytuację literatur obcych, w tym przekładów xx-wiecznych teksów z języka włoskiego w powojennej Polsce - do przełomu 1989 roku. Przypomnijmy, że po 1945 roku sterowane centralnie i poddane kontroli Centralnego Biura KPPiw wszystkie przejawy życia kulturalnego, w tym przekłady z obcych literatur, podlegały reglamentacji, a edytorstwo zostało całkowicie upaństwowione. W tym samym okresie odpowiedzialne za książkę organy nie uchylały się od roli wychowawczej, przejawiały poszanowanie dla walorów estetycznych oraz zakładały pewien program kształtowania kultury umysłowej obywateli'. Dzięki temu powodzeniem cieszyły się włoskie pozycje z repertuaru klasyki $\mathrm{xx}$ wieku (być może na decyzje te miały wpływ lewicowe poglądy i sympatie większości powojennych włoskich pisarzy i intelektualistów) i do rąk polskiego czytelnika trafiały regularnie utwory, często nagradzane, wybitnych twórców, takich jak: Giuseppe Dessì

5 Takie ujęcie uzasadnia dodatkowo fakt, że bibliografia przekładów literatury włoskiej w Polsce jest niepełna. Istnieją zbiory częściowe, porządkujące dane według kryterium przedmiotu, autora lub tłumacza. Częściowo użyteczny jest NUKAT, PBL zawiera dane od 2002 roku. Dostępne opracowania są nieciągłe i niekompletne. W takiej sytuacji także moja recenzencka buchalteria może przyczynić się do weryfikacji przeoczeń, uzupełnienia luk. Zainteresowanych recepcją odsyłam do opracowań w języku polskim, zwłaszcza do publikacji Jadwigi Miszalskiej, Moniki Gurgul, Moniki Surmy-Gawłowskiej i Moniki Woźniak: Od Dantego do Fo. Wtoska poezja i dramat w Polsce (od XVI do XXI wieku) [Miszalska, Gurgul, Surma-Gawłowska, Woźniak 2007] i Od Boccaccia do Eco: włoska proza narracyjna w Polsce (od XVI do XXI wieku) [Miszalska, Gurgul, Surma-Gawłowska, Woźniak 2011], prac poświęconych włoskiemu filmowi (w tym adaptacjom literatury) Anny Miller-Klejsy (zob. Bibliografia), monografii autorskich i współredakcji, do prac Anity Kłos: Pogrzebana poezja. O recepcji trwórczości Giuseppe Ungarettiego $w$ Polsce [Kłos 2009] i Apologia kobiecego ducha. Sibilla Aleramo i jej związki $z$ polska kultura literacka [Kłos 2018], a także do szeregu rozproszonych artykułów i rozdziałów opisujących funkcjonowanie w polskim przekładzie i odbiór tak różnych autorów, jak: Sibilla Aleramo, Alba De Céspedes, Eugenio Montale, Dino Buzzati, Umberto Saba, Andrea Camilleri, Italo Calvino i Elsa Morante.

6 Za PRL-em można czasem zatęsknić, np. kiedy czytamy, jak Zdzisław Libera podawał w 1950 roku, że za szkodliwe uznawano pozycje z zakresu kryminalistyki i niezdrowej sensacji [zob. Kitrasiewicz, Gołębiewski 2005: 33]. 
(Kraina cieni), Cesare Pavese (Księżyc i ogniska), Elio Vittorini (Ludzie czy nie?), Corrado Alvaro (Ludzie z Aspromonte), Elsa Morante (Wyspa Artura i wcześniejsza: Kłamstwo i czary)7, Alba De Céspedes (m.in. opowiadania Zaproszenie na ucztę) ${ }^{8}$, Giuseppe Tomasi di Lampedusa (Lampart), wiele dzieł Alberta Moravii (Agostino, Rzymianka, Konformista, Pogarda, Matka i córka) i Itala Calvina (Rycerz nieistniejacy, Baron drzewotaz, Wicehrabia przepotowiony, Opowieści kosmikomiczne). W powojennych dekadach obok tych publikacji w polskim przekładzie dostępne były także teksty politycznie neutralne oraz „właściwie” politycznie zaangażowane, tzn. podejmujące tematykę antyfaszystowską, poddające krytyce błędy i wypaczenia świata imperialistycznego, dzieła o wymowie antyamerykańskiej i antykapitalistycznej. I tak w PRL-u poza neorealistycznym kanonem bez przeszkód mogły się ukazywać dzieła takich pisarzy, jak antyklerykał Guido Morselli czy Dino Buzzati, autor opowiadań należących do nurtu realizmu magicznego.

Znaczne ożywienie odnotowujemy na rynku przekładów z języków europejskich, w tym włoskiego, po 1970 roku, kiedy polityczna odwilż przyniosła otwarcie na kulturę Zachodu. Równolegle z ożywieniem stosunków gospodarczych (poszukiwaniem przez Włochy nowych rynków zbytu ${ }^{9}$ ) w latach 70. i 80. politykę przekładową

7 O przełożonej Wyspie Artura pisali pochopnie (ich sądy nie wytrzymały próby czasu) w 1960 roku Billip [1960: 854-855] i Rowiński [1960: 11]. W zestawieniu z wypowiedziami o kilka lat późniejszymi - dotyczącymi drugiej przełożonej powieści Morante - autorstwa Berezy [1968: 6] i Kralowej [1968: 1248] tamte dwa emanujące paternalizmem teksty dowodzą, że recenzent nie zawsze potrafi być arbitrem i drogowskazem. A skoro o Morante mowa, wciąż dotkliwy jest brak na polskim rynku przekładów jej dzieł zaliczanych do klasyki xx wieku: La storia oraz Aracoeli. Do dziś nie przetłumaczono także I paesi tuoi Cesarego Pavesego, bardzo wielu tekstów Pier Paola Pasoliniego, Paola Volponiego, Natalii Ginzburg i innych autorów. Być może przyczyną jest niechęć wydawców przekonanych o nierentowności tego rodzaju literatury.

8 Książki tej pisarki, co ciekawe, cieszyły się w Polsce sporym powodzeniem. Świadczy o tym ton recenzji Andrzeja Hamerlińskiego [1960].

9 Grażyna Bernatowicz [1990: 7] w książce Stosunki polsko-wtoskie 1944-1989 pokazuje, jak w ślad za związkami gospodarczo-handlowymi zintensyfikowały się relacje kulturalne, co znalazło odzwierciedlenie w przekładach włoskiej literatury. W podsumowaniu rozdziału Literatura wtoska w Polsce lat 1945-1970 badaczka pisze: „[... ] podczas gdy początkowo, do 1956 r., podlegała ona [problematyka polskich wyborów przekładowych - H.S.] najwyraźniej instrumentalizacji 
zaczęto kształtować tak, by wybór tekstów udostępnianych polskim czytelnikom był reprezentatywny. Miało to umożliwić odbiorcy wyrobienie sobie poglądu na temat charakterystycznych zjawisk, prądów i dominant poszczególnych literatur narodowych. Także publikowane od 1971 roku czasopismo „Literatura na Świecie” miało podobne cele: zakładało uwzględnianie w równym stopniu walorów poznawczych, estetycznych i ideowych prezentowanych tekstów.

\section{Zasada entropii}

Po 1989 roku, jak należało oczekiwać, szybko stopniał niekwestionowany wcześniej monopol reżimu na słowo pisane. Praca wydawców przestała być reglamentowana i lawinowo zaczęły powstawać prywatne oficyny, których liczba przekracza obecnie trzydzieści tysięcy. Problemów nastręcza nam dziś nadpodaż tytułów i krótki żywot książki (w księgarni jeden tytuł jest sprzedawany najwyżej przez trzy miesiące).

Ostatnie dwie dekady przekładów współczesnej włoskiej literatury poświadczają ponadto obserwowaną od 1989 roku zasadę przypadkowości doboru przekładów, zawieszającą lansowane wcześniej kryterium reprezentatywności. Przygodność rządzącą decyzjami przekładowymi potwierdza np. kazus powieści Luki Doninellego Wracaliśmy znad morza (2007). Trudno dociec, co skłoniło wydawcę do przełożenia tej drugoplanowej książki, nawiązującej do anni di piombo, podczas gdy nieznane polskim czytelnikom pozostają wcześniejsze, klasyczne pozycje, snujące historie na tle aktów terroru, takie jak L'odore del sangue (1977) Goffreda Parisego czy niedawne wariacje na ten temat obecne w głośnej powieści Giorgia Vasty Il tempo materiale (2008). Wydanie na poły autobiograficznej powieści Doninellego prowokuje jednak do namysłu nad pamięcią rewolty 1968 roku i tzw. latami ołowiu,

i wykorzystywana była jako element propagandy, w latach późniejszych kryterium ideologiczne $\mathrm{w}$ doborze tematów stopniowo traciło na znaczeniu, by w latach 6o., czyli w okresie wzmożonej i różnorodnej recepcji, zaczęły ścierać się dwa prądy: zaangażowany, ściśle związany z kwestiami ideologicznymi i politycznymi, oraz neutralny, niezaangażowany, będący przejawem stopniowej autonomizacji wyborów przekładowych" [Bernatowicz 1990: 67]. 
które po niej nastąpily, oraz nad rolą, jaką tamten ruch odegrat. Dowiadujemy się oto, że nie wszyscy powołują się na swoją opozycyjną przeszłość. Wielu byłych kontestatorów odmawia udziału w hagiograficznym dziele, twierdząc, że Sessantotto niczego nie zrewolucjonizowało (krew rewolucji nie płynie zresztą we włoskich żyłach), było raczej rodzajem „nie-wydarzenia”, wirusem, fetyszem, buntem przeciwko rodzicom utożsamianym $\mathrm{z}$ władzą, polityką, szkołą, rodziną, religią, mieszczańską hipokryzją. Ruchem, którego przywódcy zajęli wkrótce prominentne państwowe stanowiska w tym samym społeczeństwie, którego struktury wcześniej kwestionowali. Sprowokowany czterdziestą rocznicą wysyp wspomnień, biografii, powieści i filmów o 1968 roku pokazuje, że potrzeba czasu, by podjąć wolną od emocji dyskusję wokół nierozliczonych przeszłych wydarzeń. Dziś należą do nich nadal zjawiska od Sessantotto dawniejsze: faszyzm i kolonializm.

Zastanawia także fakt - i to kolejny przykład przekładowej entropii - że nieprzekładany u nas na ogó $1^{10}$, słynący z antyklerykalizmu twórca teatru i laureat Nagrody Nobla, Dario Fo, został niedawno przybliżony polskim odbiorcom jako autor beletryzowanej biografii Lukrecji Borgii" pt. Córka papieża (2016). Nie potrafię powiedzieć, co wnosi do wiedzy polskich czytelników o włoskiej kulturze i historii przekład pierwszej powieści w karierze komediopisarza. Fo ukazuje Lukrecję jako ofiarę politycznych machinacji swojej rodziny (pochodzącej z Walencji i niezrównanej w występku), zwłaszcza ojca Rodriga (czyli papieża Aleksandra vi) i brata Cesarego (tego samego, któremu Niccolò Machiavelli zadedykował Księcia). Na nice odwraca mit Lukrecji - kobiety niegodziwej: rozwiązłej, kazirodczej manipulantki i morderczyni. Twierdzi, że w rzeczywistości była to dama rezolutna, która potrafiła sprzeciwić się rodzinie, a nawet otwarcie ją krytykować, piękna i tak

Efektem Nagrody Nobla (1997) był przekład - wcześniej, zwłaszcza na łamach czasopism, wydano pojedyncze sztuki - dwóch dramatów tego płodnego komediopisarza: Johan Padan odkrywa Amerykę i Przypadkowa śmierć anarchisty. Znana polskim czytelnikom jest też książka Daria Fo, osnuta na motywach autobiograficznych: Miasteczko nietoperzy: pierwszych siedem lat mojego życia (i jeszcze kilka). Czytelnicy mogli zapoznać się z postacią Lukrecji już w 1989 roku, kiedy ukazał się polski przekład książki Lukrecja Borgia, jej życie i czasy Marii Bellonci. 
pełna cnót (wrażliwa, sprawiedliwa, pobożna, wielbicielka sztuki teatralnej, malarstwa i poezji), że to nowe wcielenie zupełnie nie przypomina „największej kurtyzany Rzymu”.

O innych przypadkowych nieobecnych ${ }^{12}$ (m.in. literatura translingwalna i postkolonialna) będzie tu jeszcze mowa. W przekładach nadal pomijane są także pozycje z kręgu niezwykle popularnej w Italii literatury o prekariacie. To nurt najczęściej krótkich powieści i tekstów non-fiction, których głównym bohaterem jest kurczący się i nieprzyjazny młodym rynek pracy, poza pracą w call center oferujący jedynie wspól-pracę, prace dorywcze, zlecone, ale nigdy umowę o pracę. Dziwi nieco, że dość świeża jeszcze pamięć przyjmowanych $z$ entuzjazmem w PRL-u przekładów takich pozycji, krytykujących bezwzględne mechanizmy świata kapitalistycznych przedsiębiorstw, jak Donnarumma atakuje Ottiero Ottieriego (1963) czy Pryncypał Goffreda Parisego (1969), nie wpływa w jakiś sposób na obserwowany dziś w Polsce wyraźnie (niechętny) stosunek do częstych tematów włoskiej literatury ostatnich lat (należą do nich właśnie bezrobocie młodych i zwykle dobrze wykształconych ludzi, kurczące się perspektywy zawodowe całych kolejnych pokoleń).

\section{Od eseistyki i literatury faktu po kryminały}

\section{i beletryzowane scenariusze}

Zdecydowanie zyskały ostatnio na wartości akcje włoskiej eseistyki (i literatury faktu, o czym za chwilę), która przed 2000 rokiem ukazywała się sporadycznie i w wybranych fragmentach. I tak, nie licząc Umberta Eco, którego powieści oraz eseje mogą być raczej przedmiotem rywalizacji wydawców (przełożono na język polski wszystkie bodaj dzieła, zbiory felietonów i wykładów, które wyszły za życia autora i po jego śmierci), możemy zapoznać się z kilkoma erudycyjnymi zbiorami esejów autorstwa pisarza i wydawcy Roberta Calassa - od Literatura i bogowie (2011) przez K. (2011), Zaślubiny Kadmosa z Harmonia (2010), Ślad wydawcy (2018) po

Nieoczywiste decyzje prowadzić mogły z kolei np. do wydania przekładu tomu poetyckiej prozy pt. Geografie (2014) autorstwa mało znanego współczesnego pisarza Giovanniego Catellego. 
Nienazwana teraźniejszość (2019); poznać niezwykle zajmujące teksty włoskiego Ciorana, erudyty Guida Ceronettiego: Milczenie ciała: materiały do studiów medycznych (2004), a także publikacje innych autorów: Laboratoria zmysłów Piera Camporesiego (2005), Wyjście z labiryntu. Szkice rozproszone z lat 1943-1952 Alberta Savinia (2001), Co pozostaje. Notesy 1955-1971 (2001), Notatki (2015) i Listy do Muszki (2018) europejskiego humanisty i wielkiego outsidera Nicoli Chiaromontego, filozoficzne rozprawki Rema Bodei $O \dot{z y c i u ~ r z e c z y ~}$ (2016), wreszcie ogromną liczbę książek i artykułów Giorgia Agambena, wśród których najważniejsze to: Profanacje (2006), Homo sacer. Suwerenna wtadza i nagie życie (2008), Co zostaje z Auschwitz. Archiwum i świadek (2008), Wspólnota, która nadchodzi (2008), Stan wyjątkowy (2009), Czas, który zostaje. Komentarz do Listu do Rzymian (2009), Nagość (2010), Co dalej z demokracją (2012), Piłat i Jezus (2017), Przyjaciel (2017), Heidegger i nazizm (2018), Idea prozy (2018), Mesjasz i suweren. Problem prawa u Waltera Benjamina (2019). Wzrósł również przekład eseistyki literackiej, adresowanej przecież do znacznie węższego grona odbiorców. Wśród nich wymieńmy - oczywiście poza esejami takich gigantów, jak Eco czy Magris $^{13}$ - eseje autorstwa Giuseppe Tomasiego di Lampedusy: Szekspir (2001) i O Stendhalu (2003).

Literatura faktu cieszy się naturalnie w kraju Ryszarda Kapuścińskiego dużym zainteresowaniem. Po 2000 roku polski czytelnik znajdzie bogatą ofertę książek pióra pisarzy, reportażystów i reporterów, takich jak Stefano Liberti (autor książek Na południe od Lampedusy: podróże rozpaczy, 2013 i Władcy jedzenia. Jak przemyst spożywczy niszczy planetę, 2019) czy Riccardo Orizio, finalista Nagrody im. Ryszarda Kapuścińskiego (autor książki Zaginione biate plemiona. Podróż w poszukiwaniu zapomnianych mniejszości, 2009). Na kolejnym miejscu plasują się teksty non-fiction wybitnego włoskiego polonisty Francesca Cataluccia: Niedojrzałość, choroba naszych czasów (2006), Jadę zobaczyć, czy tam jest lepiej. 
Niemalże brewiarz środkowoeuropejski (2012) i Czarnobyl (2013). Zwolenników prozy reportażowej, podróżniczej i esejów Oriany Fallaci (cztery jej książki ukazały się w Polsce przed rokiem 2000, a tuzin już w XXI wieku) z pewnością ucieszył przekład książki pt. Oriana Fallaci: portret kobiety pióra mieszkającej w Paryżu włoskiej dziennikarki Cristiny De Stefano (2014). Warto przypomnieć, że ukazały się również liczne przekłady dzieł porównywanego często z Fallaci dziennikarza i pisarza Tiziana Terzaniego: Nic nie zdarza się przypadkiem (2008), Zakazane wrota (2011), Listy przeciwko wojnie (2012), W Azji (2009), Powiedziat mi wróżbita: lądowe podróże po Dalekim Wschodzie (2008), Duchy: korespondencja $z$ Kambodży (2016), Koniec jest moim początkiem (2017). Katalog ten uzupełniają ostatnie reportaże zaangażowane autorstwa Luki Rastelli - Przemytnik doskonaty: jak transportować tony kokainy i żyć szczęśliwie (2013) - i na poły poetyckie Paola Rumiza, np. Legenda żeglujących gór (2016) ${ }^{14}$.

Zjawisko rosnącej popularności odmiany non-fiction tłumaczyć można na różne sposoby. Niefikcyjny dyskurs odzyskuje lub zastępuje przestarzałe (przednowoczesne) formy historiografii lub z nią rywalizuje na polu literatury. Zarazem historiografia postrzegana jest jako nieskuteczna. Czynnikami sukcesu odmiany non-fiction są etyczne zaangażowanie twórcy oraz potrzeba autentyczności i nowości, natomiast głównym impulsem jest zmęczenie zapośredniczeniem, filtrem, medium - poszukiwanie bliskiego kontaktu z rzeczywistością. Także proza detektywistyczna może powstawać z potrzeby włączenia się głosu twórcy w debatę nad współczesnymi mu bolączkami (korupcja, mafia, nielegalne wysypiska śmieci, imigracja, brak pracy, prekariat itd.). Głównym tej prozy żywiołem nie jest jednak j'accuse, lecz rozrywka. Nie zaskakuje zatem fakt, że wydawcy chętnie publikują przekłady włoskich kryminałów i thrillerów. Obraz włoskiej prozy gatunkowej prezentuje się nader ciekawie, nakłada się nań bowiem dodatkowo zróżnicowanie regionalne i językowe (choć to ostatnie zazwyczaj ginie w przekładzie).

14 Także książki popularyzujące naukę spotykają się dziś z zainteresowaniem wydawców. Na polski regularnie przekładane są np. prace włoskiego fizyka Carla Rovelliego. 
I tak poza książkami niedawno zmarłego króla współczesnego włoskiego kryminału w ogóle i kryminału historycznego w szczególności, sycylijczyka Andrei Camilleriego (z komisarzem smakoszem i zatwardziałym singlem Salvem Montalbanem), możemy czytać powieści z dreszczykiem napisane przez neapolitańczyka Maurizia De Giovanniego (z krnąbrnym komisarzem Luigim Alfredem Ricciardim w roli głównej), a także kryminały północy: Fulvia Ervasa z regionu Veneto, thrillery historyczne wywodzącego się z Emilii-Romanii Marcella Simoniego i thrillery urodzonej w Turynie Eleny Varvello oraz sensacyjne książki pochodzącego z Bolzano Luki D’Andrei. Ostatnio rekordy popularności bije seria powieści Ilarii Tuti (wywodzącej się z Friuli) i jej bohaterka Teresa Battaglia - starzejąca się i tracąca pamięć wskutek choroby otępiennej komisarz. Wcześniej (poza Camillierim) zdecydowanie najbardziej poczytne były książki Gianrica Carofiglia, byłego sędziego z Bari, należące do pododmiany legal thrillers, z sympatycznym adwokatem Guidem Guerrerim w roli głównej. W parze z literaturą gatunków idą popularne powieści historyczne Roberta Fabbriego, neohistoryczne ${ }^{15}$ powieści Roberta Pazziego oraz teksty etnograficzne czy folklorystyczne Alberta Angeli, rekostruujące szczegóły życia codziennego minionych epok, np. starożytnego Rzymu.

Także beletryzowane scenariusze i powieści autorów ukształtowanych w szkołach kreatywnego pisania to pola szybko się rozwijające i zyskujące coraz większe znaczenie. Warto podkreślić, że jest to zjawisko o charakterze globalnym, a nie tylko obserwowane w jakimś jednym kręgu kulturowym, i dotyczy różnych autorów, a nie wyłącznie autorów superpopularnych czytadel, jak Równanie mitości Simony Sparaco czy Samotność liczb pierwszych (dzieło poruszające problemy lęku, samotności, rozpadu rodziny, a także samookaleczania i innych zaburzeń wieku dorastania) Paola Giordana. Przekładane są na język polski także takie teksty, jak postprodukcyjny, beletryzowany scenariusz Paola Sorrentina Młodość czy tegoż Nieistotne wizerunki, szkice do scenariuszy i portrety postaci,

15 Neologizm „powieść neohistoryczna”, będący przekładem włoskiego romanzo neostorico (i ang. new historical novel), uwzględnia odniesienie do założeń nowego historycyzmu, które realizuje postmodernistyczna powieść historyczna. 
z których każda ze swoją osobliwą historią aspiruje do rangi bohatera kolejnego filmu. Ukazała się również Korespondencja Giuseppego Tornatorego, dość upiorna przypowieść o nieskończonych możliwościach wirtualnej (czasami niezwykle uciążliwej) obecności, także po śmierci, w dalszym życiu bliskiej osoby, uzyskanej dzięki dostępowi do Internetu oraz innych mediów. Te ostatnie przekłady wydał Rebis w serii Bel Paese. Mistrzowie Współczesnej Literatury Włoskiej. To swoisty znak czasów: dawniej na dalekich miejscach w rankingach przekładów literatur narodowych, teraz włoska literatura zdobywa odrębne serie, niejednokrotnie dzięki środkom wyasygnowanym przez włoskie ministerstwo. Często literatura popularność zawdzięcza ekranizacji. Tak było np. ze sfilmowaną przez Nanniego Morettiego powieścią Spokojny chaos (wyróżnioną w 2006 roku nagrodą Premio Strega) autorstwa Sandra Veronesiego. Draft Publishing otwarło tą pozycją serię Europa Odnaleziona, torując w ten sposób drogę na polskim rynku innym tytułom współczesnej literatury europejskiej.

\section{World fiction: wielcy wygrani współczesnej literatury włoskiej w przekładzie}

Druga dekada Xxi wieku przyniosła uzupełnienia braków w przekładach klasycznych pozycji najważniejszych xx-wiecznych pisarzy. Zaczęto wydawać klasyków xx wieku w najlepszych przekładach. W 2010 roku pojawiła się retranslacja Lamparta Lampedusy (Geparda w nowym tłumaczeniu Stanisława Kasprzysiaka), w 2011 roku ukazała się powieść Jeden, nikt, sto tysięcy Luigiego Pirandella w przekładzie Joanny Ugniewskiej oraz kilka wcześniej nietłumaczonych tekstów Calvina (trzytomowe baśnie włoskie). Nasze dni wczorajsze znakomitej Natalii Ginzburg przełożyła Alina Pawłowska-Zampino w 2017 roku, najwyższej próby prozę Giorgia Bassaniego: Między murami i Złote okulary, a ostatnio Radę egipska Leonarda Sciasci otrzymaliśmy w mistrzowskim przekładzie Haliny Kralowej. Opowiadania Morze karaluchów Tommasa Landolfiego wydano w przekładzie Anny Wasilewskiej, której zawdzięczamy także nowatorską językowo translację Niezłego pasztetu na via Merulana Carla Emilia Gaddy. Z kolei wyśmienite mikronarracje 
Giorgia Manganellego zebrane w książce Centuria. Sto krótkich powieści rzek ukazały się w przekładzie Kralowej. Jarosław Mikołajewski, niezwykle zasłużony dla przekładów poezji ${ }^{16}$, spolszczył niedawno Ernesta Umberta Saby.

Do kategorii naprawiania historycznych przeoczeń można zaliczyć także decyzję o przekładzie przez lata cenzurowanej w Italii Sztuki radości kontrowersyjnej pisarki Goliardy Sapienzy. Jakość przekładu pozostawia niestety wiele do życzenia, choć dobrze, że w ogóle został wydany. Zresztą włoskie pisarki cieszą się u nas sporym powodzeniem już od 1989 roku, a to za sprawą liczebnej przewagi czytelniczek nad czytelnikami oraz z racji tego, że tak wiele kobiet uprawia dziś ten zawód. Pisarki, których dzieła niemal w całości zostały przełożone na język polski, to przede wszystkim popularna u nas Fallaci, urodzona w Szwajcarii Fleur Jaeggy, mieszkająca w Anglii Sycylijka Simonetta Agnello-Hornby, i pół-Angielka, pół-Włoszka Margaret Mazzantini (jej popularności nie przyćmiła nawet Ferrante Fever). Pojawiło się także kilka książek Dacii Maraini, Melanii Mazzucco, cztery teksty Susanny Tamaro (dwa po 2000 roku) i dwa teksty piszącej po włosku Albanki Orneli Vorpsi (Kraj, gdzie nigdy się nie umiera, 2008 i Ręka, której nie kąsasz, 2009). Poza tym ukazały się dwie powieści Giuliany Morandini, do których należy dodać liczne książki Svevy Casati Modignani i po jednej autorstwa Laury Pariani (Gombrowicz i Buenos Aires: historia pewnego przektadu, 2006), Marii Rosy Cutrufelli (Brygantka, 2010) i Sandry Petrignani (Domy pisarek, 2004). Wielkiej Ginzburg

W ostatnich latach ukazały się nieliczne przekłady poezji włoskiej. Autorem niemal wszystkich jest poeta i tłumacz Jarosław Mikołajewski, który przetłumaczył: tomiki Eugenia Montalego, Aldy Merini, Salvatore Quasimodo i kilka antologii poezji Xx-wiecznej. Zresztą sytuacja (nie tylko) włoskiej poezji w przekładzie i w oryginale na polskim rynku wydawniczym jest nie najlepsza. Odsyłam do aktualnych badań nad recepcją włoskiej poezji w Polsce prowadzonych przez Katarzynę Misiewicz. Część swoich ustaleń ogłosiła w artykule, którego jestem współautorką, pt. Tutto (si) è globalizzato? Sulla letteratura italiana nella Polonia dopo la caduta del muro [Misiewicz, Sekrowska 2016]. Poza liryką tradycyjnie najgorzej miewają się też teksty teatralne. Tu polskie przekłady zawdzięczamy Ewie Bal, Jolancie Dygul i Cezaremu Bronowskiemu. Można natomiast zauważyć większe zainteresowanie literaturą dziecięcą. Ukazują się kolejne przekłady książek Gianniego Rodariego, a retranslacji Pinocchia Carla Collodiego jest bez liku. 
możemy przeczytać po polsku nadal tylko dwie powieści. Drogi Michele została wydana w 1976 roku, a Nasze dni wczorajsze w 2014 roku. Po 1989 roku nie ukazało się już ani jedno tłumaczenie książki Alby De Céspedes, która w poprzednich latach miała wyjątkowe szczęście do przekładów (dostępnych jest aż pięć publikacji jej autorstwa).

Regularnie wydawane są też książki, które odzwierciedlają rysujące się trendy i mody, prezentujące poczytnych autorów, zwłaszcza teksty adresowane do młodego czytelnika, powieści młodzieżowe i pokoleniowe. Do takich należą powieści gwiazdy włoskiej prozy postmodernodenistycznej Alessandra Baricca (łącznie ukazało się do dziś w polskim przekładzie dziesięć książek tego autora) czy Niccolò Ammanitiego nazywanego włoskim Stephenem Kingiem (m.in. Ostatni sylwester ludzkości, 2000, Bagno, 2001, Zabiorę cię ze soba, 2002, Nie boję się, 2003, Jak Bóg przykazat, 2008). Warto odnotować także przekład fenomenalnej powieści młodzieżowej Enrika Brizziego, Jack Frusciante opuszcza grupe (2004) czy powieści pokoleniowej Leżący autorstwa Michele Serry (2016). Przełożone zostały także dwie inne książki: oparta na doświadczeniu autobiograficznym publikacja o dziecku z zespołem Downa, Urodzeni dwa razy (2002) Giuseppego Pontiggi, oraz mocno podstarzała już, inspirowana technikami kina proza słynnego w latach 8o. Andrei De Carla (wcześniej ukazało się tylko tłumaczenie jego Morza prawd, 1996): Śmietankowy pociag (2007) i Niedoskonaty cud (2017).

Zanim przejdziemy do największych wygranych ostatnich lat, pisarzy odnoszących globalne sukcesy, kilka słów poświęcić pragnę nieobecności w polskim przekładzie włoskojęzycznych pisarzy postkolonialnych i translingwalnych. Ich tekstów - poza dziełami Vorpsi - nadal u nas jak na lekarstwo, podczas gdy we Włoszech tworzą one już oddzielną, poczytną kategorię. Prawdopodobnie aby „zasłużyć” na polski przekład potrzebna jest silna tożsamość narodowa, a my być może nie uwolniliśmy się jeszcze od kompleksu społeczeństwa, którego przetrwanie związane było z językiem. Polski rynek przekładowy rejestruje w obszarze literatury migrante zjawiska odwrotne do tych charakteryzujących rynek niemiecki czy francuski. 
Poza tym właśnie $z$ francuskim rynkiem wydawniczym łączą nasze rodzime oficyny bliskie stosunki. Efektem jest m.in. to, że książki uznanego we Francji pisarza niemal natychmiast trafiają do rąk polskich czytelników. Przykładem niech będą teksty Mileny Agus, Micheli Murgii, a zwłaszcza Erriego De Luki, który w opracowaniu francuskich literaturoznawców pt. Literatura Europy. Historia literatury europejskiej (2009) [Corbel 2009: 1027] został uznany za najwybitniejszego współczesnego włoskiego pisarza i awansowany do rangi pisarza europejskiego. Mogło to wprawić w zdumienie zarówno badaczy, czytelników, jak i samych gigantów współczesnej włoskiej sceny literackiej: Umberta Eco, Antonia Tabucchiego, Claudia Magrisa, a nawet - jeśli przyjąć kategorię czytelnictwa - Andrei Camilleriego. Wróćmy zatem do wspomnianej nieprzychylności czy niegotowości do przekładu tekstów o tematyce postkolonialnej i pisanych w języku włoskim przez tzw. migrant writers. Jest to zjawisko zasługujące na refleksję choćby przez wzgląd na pewną asynchroniczność ideologicznych przesłanek. Podczas gdy w Italii lewicowi intelektualiści i pisarze $^{17}$ sprzyjają od kilku już dekad krytyce kolonialnej przeszłości, późniejszego neokolonializmu i innych przejawów imperializmu, w Polsce podobną krytykę spotkać można raczej na łamach prasy, w pismach fachowych i w opracowaniach akademickich, ale nie znajduje ona odzwierciedlenia w przekładowych wyborach.

Dobrym łącznikiem tekstów migracyjno-postkolonialnych z odmiany world fiction, reprezentowanej przez grupę pisarzy, których można uważać za wygranych ostatnich dwóch dekad, jest proza Mazzantini, znanej z beletryzowanych scenariuszy systematycznie przenoszonych na ekran. W polskim przekładzie ukazały

17 Jerzy Niecikowski i Wacław Sadkowski [1973: 742] w artykule Glosa do artykułów Stefana Morawskiego ogłoszonym na łamach „Literatury na Świecie” piszą o obserwowanej w ówczesnej polskiej kulturze krytyce zachodniej „huralewicowości typu mieszczańskiego” występującej w „lewackich, ekstremistycznych ruchach politycznych", które na dodatek poważnie wypaczały marksizm. Źródło to cytuję za pracą Małgorzaty Ślarzyńskiej [2017: 97], według której w latach 80. Sadkowski wypowiadać się będzie o przekładach podejmowanych bezkrytycznie, w nielegalnych wydawnictwach i ze szkodą dla obrazu zachodniej kultury, $\mathrm{w}$ fanatycznym kulcie Zachodu. 
się jej utwory, m.in. Powtórnie narodzony (2013), Nikt nie ocali się sam (2016), Blask (2016), Zatrzymaj się (2004 wyd. Muza i 2018 wyd. Sonia Draga). Na rangę wspomnianego łącznika zasługuje natomiast najciekawsza pod wieloma względami, choć króciutka, powieść autorstwa tej pisarki - Morze o poranku. Jej tłumaczenie stanowi bodaj jedyne odstępstwo od reguły nieprzekładania na język polski tekstów piszących po włosku pisarzy i pisarek postkolonialnych oraz tekstów powiązanych tematycznie $\mathrm{z}$ historią włoskiego kolonializmu. W tej świetnej lirycznej powieści autorka opisuje splatające się ze sobą losy Libijczyka i Włocha na tle wydarzeń, które doprowadziły do ustanowienia kolonii włoskiej w Afryce. Nawiązuje do wyścigu międzynarodowych koncernów naftowych po odkryciu złóż ropy, do zamachu stanu Kadafiego w 1969 roku, wojny domowej oraz śmierci tyrana w 2011 roku.

Wreszcie pora na globalny bestseller w języku włoskim - kierujący się swoimi prawami i przynoszący dobrze skalkulowane zyski i jego polskie przekłady. Tacy giganci, jak: Roberto Saviano, Elena Ferrante, Domenico Starnone, Margaret Mazzantini, Federico Moccia - to prawdziwe literackie marki, gwarancje sukcesu. Ich książki tłumaczone są równocześnie na kilka języków, promowane globalnie, filmowane. Poza Starnonem (którego dzieła wydaje w Polsce oficyna W.A.B.) wszyscy ci autorzy są znani polskiemu czytelnikowi głównie dzięki wydawnictwu Sonia Draga. Dzieła Saviana - pisarza upominającego się o sprawiedliwość i wolność od przestępczości (za swoje teksty zapłacił wolnością i od 2006 roku żyje w ukryciu) - mieliśmy sposobność czytać w polskim przekładzie. Były to zarówno powieści non-fiction (Gomorra, 2008, 2009, 2010, 2011 w oficynie Czytelnik i 2014, 2018 w oficynie Sonia Draga, ZeroZeroZero, 2014 i 2020, Chtopcy z paranzy, 2018, Drapieżny pocałunek, 2019), jak i eseje zebrane w tomie Piękno i piekło (2010).

Tetralogia Ferrante o toksycznej przyjaźni dwóch neapolitańskich dziewcząt utorowała drogę przekładom wcześniejszych sygnowanych tym pseudonimem książek, powiązanych tematycznie z Genialna przyjaciótka, lecz stylistycznie zupełnie od niej odmiennych, jak Córka (2017), Obsesyjna miłość (2018), Czas porzucenia (2020). Ostatnio w polskim przekładzie ukazała się także tematycznie wtórna wobec tetralogii, najnowsza sygnowana 
tym nome de plume powieść: Zakłamane życie dorostych (2020). Starnone, być może piszącego w duecie z (osobą kryjącą się za pseudonimem) Ferrante, także mogliśmy już poznać w Sznurówkach (2017) i Psikusie (2018). Do grona nowych włoskich autorów world fiction zaliczyć można także wspomnianą już Mazzantini jako autorkę beletryzowanych scenariuszy (wpisana od początku w tekst podatność na ekranizację decyduje o przynależności do kategorii prozy globalnego sukcesu).

Są to autorzy tekstów komponowanych seryjnie - jak kryminały Camilleriego, jedenaście tekstów tworzących archipelag autorstwa Mocci czy ostatnio tetralogia Ferrane - co „fidelizuje” czytelnika, spełnia jego potrzebę immersji, wręcz uzależnia (prowadzi ponoć do binge reading) i skutecznie ruguje konkurencję (dając wydawcy większą gwarancję zwrotu poniesionych nakładów). To bardzo ważne, zwłaszcza że w naszych ahistorycznych czasach żywot książki jest niezwykle krótki, a jej przydatność do spożycia mierzy się w tych samych kategoriach, które odnoszą się do rynkowych produktów. Pisarze world fiction często utrzymują bezpośredni kontakt z czytelnikiem za pośrednictwem bloga. Takie działanie skutecznie wpływa na losy książki i pełni podwójną funkcję - jak zauważa Milena Rachid Chehab [2016]. Z jednej strony wydawcy zachęcają autora, żeby prowadził bloga, stronę na Facebooku lub był aktywny w innych mediach społecznościowych, gdyż pragną utrzymać stały kontakt z potencjalnymi nabywcami jego książek. $\mathrm{Z}$ drugiej to na podstawie bloga wydawca podejmuje decyzję wydawniczą, konsultuje się też z czytającym manuskrypty łowcą talentów zwanym skautem.

Nawiasem mówiąc, cechą charakterystyczną polskiego rynku przekładów po 1989 roku jest obserwowane przez pewien czas przywiązanie wydawców do wybranych autorów tekstów. I tak np. dzieła Tabucchiego ukazywały się nakładem wydawnictwa Czytelnik, Camilleriego, i Jaeggy - włoską pisarkę o szwajcarskich korzeniach i stylu zbliżonym do Agoty Kristoff - prezentowało polskim odbiorcom Noir sur Blanc. W.A.B. wydało dzieła Mazzucco, Carofiglio i Agus. Z kolei Świat Książki opublikował teksty Murgii, a Muza - Baricca, Ammanitiego i Mocci. Najmłodszy wydawniczy gigant specjalizujący się w literaturze przekładowej, Sonia Draga, 
wydaje dzieła Ferrante, Saviana, Mazzantini. Oficyna ta opublikowała także książki Giseppego Catozzella - Nie mów, że się boisz (2014), laureata młodzieżowej edycji Premio Strega, kryminały Roberta Costantiniego, thrillery historyczne Simoniego i thrillery Tuti oraz - do czego przejdziemy za chwilę - najnowszą książkę non-fiction Antonia Scuratiego. Do oficyn wydających włoskie przekłady zaliczyć także należy Wydawnictwo Dolnośląskie, które postawiło na pozycje klasyczne: List do nienarodzonego dziecka Fallaci (1993), Lamparta Lampedusy (1993), Dekarmeron Giovanniego Boccaccia (1994), Skórę Curzia Malapartego (1998), a także na superpopularne pozycje, jak Czekam na ciebie cate życie Fabia Volo (2005), którego przekłady później przejęła oficyna Muza (opublikowała Jeszcze jeden dzień i Pierwsze światta poranka, 2012). Czytadła Melissy P. wydają Prószyński i S-ka (Sto pociagnięć szczotka przed snem, 2005 - notabene dość niefortunnie brzmi ten tytuł książki w przekładzie) i Wydawnictwo Albatros Andrzej Kuryłowicz (Zapach twojego oddechu, 2007). Dzieła Baricca wcześniej wydawał Czytelnik, zaś w 2018 roku ukazały się kolejne dwa tytuly tego pisarza: Panna młoda i Mr Gwyn nakładem katowickiej oficyny Sonia Draga.

\section{Ur-Faszyzm, Premio Strega dla Antonia Scuratiego i wniosek}

Ważną rolę w procesie decyzyjnym dotyczącym przekładów odgrywają nagrody literackie, zwłaszcza najważniejsza nagroda we Włoszech: Premio Strega. W 2018 roku ukazała się w polskim przekładzie powieść Osiem gór Paola Cognettiego, laureata Premio Strega 2017. Rok wcześniej nagrodzona została, także przełożona na język polski, Dzikość Nicoli Lagioi, a w 2019 roku to prestiżowe wyróżnienie otrzymała opasła powieść M: syn stulecia Scuratiego (o której za chwilę).

Jednak zasada nagrody Strega nie działa tak samo w każdym przypadku. Nie ma i pewnie nie doczeka się przekładu licząca blisko tysiąc trzysta stron La scuola cattolica Edoarda Albinatiego, Resistere non serve a niente słynnego autora non-fiction Waltera Sitiego czy autobiograficzna powieść Il desiderio di essere come tutti Francesca Piccolo. Nie cieszy się u nas szczególnym zainteresowaniem 
twórczość Heleny Janeczek. Ukazała się do tej pory tylko jedna jej książka - z oczywistych względów - Jaskótki z Monte Cassino (2010), ale już nie (w każdym razie jeszcze nie) nagrodzona Premio Strega 2018 La ragazza con la Leica czy znakomita debiutancka powieść oparta na motywach autobiograficznych - Lezioni di tenebra. Nie wiadomo, czy któraś z polskich oficyn zaryzykuje wydanie Kolibra Veronesiego (to tegoroczny laureat nagrody) - dzieła, w którym mowa o bólu i o śmierci (tematach ostatnio całkiem na czasie).

W obserwowanym przez nas wycinku włoskich przekładów ciekawym studium przypadku, nad którym warto się zatrzymać aby poszerzyć naszą perspektywę o denotowane tym pojęciem zjawiska - jest dzieło poświęcone włoskiemu faszyzmowi, a więc zjawisku w XX-wiecznej historii Włoch, które dopiero sto lat później przestaje być kulturowym tabu. Po latach ogromnej pracy wykonanej przez historyków, takich jak Renzo De Felice - na ponad siedmiu tysiącach stron publikujący ustalenia wnikliwych badań każdego niemal aspektu historii faszyzmu ${ }^{18}$ - zjawisko to wciąż intryguje, bo, jak pokazuje Scurati, sami Włosi niewiele o nim wiedzą. Wiedzę polskich czytelników na temat faszyzmu kształtował m.in. szereg tekstów literatury włoskiej dostępnych w przekładzie, ukazujących się w ciągu ostatniego sześćdziesięciolecia, jeśli przyjąć, że okres ten otwiera wydana w 1952 roku powieść Vasca Pratoliniego Ulica ubogich kochanków (1947), a zamyka - z uwagi na dotychczasowy brak rozliczenia się przez Włochów z historią, faszyzmem, ruchem oporu i powojennymi samosądami czy szerzej wojenną i powojenną historią - wydana w polskim przekładzie w 2020 roku powieść M. Syn wieku Scuratiego (2019) ${ }^{19}$. Dodajmy, że klamra ta obejmuje także teksty poświęcone walce z faszyzmem,

Renzo De Felice poświęcił kilka dekad badaniom nad faszyzmem, związkom intelektualistów, pisarzy i artystów z faszyzmem, opisał historię włoskich Żydów w czasach faszyzmu, stworzył fotograficzną historię faszyzmu, zebrał analizy historyczne, polityczne i kulturowe oraz interpretacje faszyzmu prezentowane przez współczesnych historyków, zbadał mit Benito Mussolinego i antyfaszyzm. Ślarzyńska [2017: 65] przywołuje wypowiedzi znawców literatury włoskiej z połowy xx wieku, wskazujące na ideologiczne uzasadnienie (np. treści antyfaszystowskie) wyborów przekładowych z literatury włoskiej w ciągu kilku dekad powojennych, i stwierdza, że wybory te oraz dyskurs wokół literatury włoskiej były obciążone „wyraźnym znamieniem ideologicznym”. Między innymi anty- 
znacząco niuansujące, jeśli nie relatywizujące, przesłanki, które skłaniały Włochów do przyłączenia się do włoskiego ruchu oporu. Należą do nich książki Ścieżka pajęczych gniazd Calvina (1957) czy Pewna prywatna sprawa Beppego Fenoglia (1979), choć próżno by szukać w tym gronie powieści Ginzburg, a przecież ważną rolę odgrywają w nich motywy antyfaszystowskie. Poza tym mający wyraźny wydźwięk antyfaszystowski włoski kanon neorealistyczny tłumaczono w polskim powojniu niemal natychmiast. Należały do niego takie teksty, jak: Chrystus zatrzymat się w Eboli Carla Leviego (1949), Agnieszka idzie na śmierć Renaty Viganò (1951), Ulica ubogich kochanków i Metello Vasca Pratoliniego (1952 i 1957), Pamiętnik fryzjera Giovanniego Germanetta (1951), Starzy towarzysze (1955) i Jego dziewczyna (1962) Carla Cassoli ${ }^{20}$, Ludzie czy nie Elia Vittoriniego (1958), Fontamara Ignazia Silonego (1960) ${ }^{21}$.

Poświęćmy więc na koniec uwagę tej monumentalnej, liczącej blisko siedemset stron powieści Scuratiego. Jej omówienie (recenzja), zamieszczone na łamach „Nowych Książek”, pełni - jak ufam - wspomnianą na wstępie funkcję: kieruje uwagę na pozycje mogące aktywnie kształtować czytelniczą wiedzę o kulturze i historii Włoch, a nawet naszą świadomość w ogóle. Pisarzowi też przyświeca taki zamiar. Scurati z jednej strony zapewnia, że nie ma ambicji historyka, z drugiej natomiast pisze powieść, którą opatruje etykietą „,dokumentalna”, a na jej okładce umieszcza rekomendację specjalisty od non-fiction Saviana. W rzeczywistości mamy do czynienia z beletryzowaną biografią Mussoliniego i drobiazgową kroniką faszyzmu (od powstania związków bojowych w 1919 roku do stycznia $1925 \mathrm{roku}$ ) w jednym. W wywiadach pisarz zwraca uwagę na ogromny wykonany research i autentyczny charakter rekonstrukcji owego bezprecedensowego zjawiska, jakim był

faszyzm jawił się „,jako najsłuszniejsze uzasadnienie przekładów z literatury włoskiej" [Ślarzyńska 2017: 65].

W przypadku tego ostatniego pisarza odnotować warto dodatkowo, że polski przekład Starych towarzyszy (1955) był pierwszym zagranicznym tłumaczeniem dzieła Carla Cassoli w ogóle. W 2017 roku staraniem Alby Andreini została zorganizowana wystawa i powstał katalog poświęcony obecności dzieł pisarza poza granicami Włoch pt. Sconfinamenti. Le terre lontane di Cassola. Mostra su Cassola oltre frontiera [zob. Pogońska-Baranowska (w druku)]. 
faszyzm. Podkreśla zdumienie własną niewiedzą i tym, co odkrył podczas badania źródeł związanych $\mathrm{z}$ faszyzmem, którego rzekomo nie rozumiemy i wypieramy ze świadomości, a różne partie polityczne przywołują go tendencyjnie.

Przypomnijmy artykuł Eco [1995] zatytułowany Ur-Fascism. Autor zwraca w nim uwagę na istnienie pewnej obsesji związanej z faszyzmem, przez co samo słowo „faszyzm” stało się all purpose term, rodzajem synekdochy używanej do określenia różnych ruchów totalitarnych. Faszyzm został w ten sposób ur-faszyzmem, wiecznym faszyzmem, natomiast sam faszyzm został pozbawiony esencji. Zawiera w sobie elementy wszystkich późniejszych form totalitaryzmu, a to za sprawą samej natury ruchu, opisanego przez Eco jako „kolaż różnych idei filozoficznych i politycznych”, „ul sprzeczności”. Sam faszyzm nie był całkiem totalitarny, bo nie stworzył żadnej filozofii, posługiwał się wyłącznie retoryką. Obraz wyłaniający się z biografii M: syn stulecia jest do wizji Eco zbliżony. Scurati wykorzystuje dobrze poświadczone dane historyczne, a zarazem próbuje dociec, skąd wziął się faszyzm. Naukowe źródła wykorzystywane przez historyków w konstrukcjach historii zdarzeniowej, uwzględniającej fakty odpowiadające na pytania: „kto, gdzie, kiedy", uzupełnia domysłami mającymi wyjaśnić okoliczności zdarzeń (pobudki, instynkty i nastroje jednostek i grup społecznych) oraz elementami mentalnościowymi. Książka jest kopalnią wiedzy o zjawisku faszyzmu, jego ukorzenianiu się w świadomości Włochów i w historycznej rzeczywistości. Ukazuje faszyzm jako coś nowego, czego wcześniej nie było, coś w rodzaju antypartii, uprawiającej antypolitykę, jako tego trzeciego, który korzysta (na rozgrywkach między kapitalizmem a komunizmem). To dynamiczny ruch zbudowany poza strukturami tradycyjnej polityki, przeciw elitom, w obronie wykluczonych mas, prezentujący się jako postępowy, lecz posługujący się przemocą.

Sam Duce - który po porażce w wyborach 1919 roku zastanawiał się nad porzuceniem polityki na rzecz teatru - został ukazany w książce jako dalekowzroczny zdrajca, mistrz lawirowania, hipokryzji i kompromisu, rewolucjonista albo konserwatysta, zależnie od okoliczności, wykorzystujący nastroje populista. Mussolini to kolejno: oskarżony przez towarzyszy socjalistów o zdradę poli- 
tyczną i wydalony z partii (prywatnie syn kowala, samolubny samiec, syfilityk), pertraktujący ze wszystkimi, wszystkim obiecujący to samo: objęcie sterów rządu koalicyjnego, i wszystkich oszukujący. Grający na zwłokę, aby doprowadzić kryzys polityczny do punktu, w którym nie ma już alternatywy dla rządu faszystów, i przejąć władzę bez rozlewu krwi. Ów urodzony despota, zdolny do ujarzmienia mas triumfator, wyczekiwany przez naród przygnębiony skutkami niekończącego się konfliktu, nazwany wreszcie zostaje mężem opatrznościowym (taki też jest tytuł drugiej części trylogii Scuratiego, która ukazała się w Italii i jest już tłumaczona na język polski).

Niech mi będzie wolno zakończyć tekst wnioskiem wynikającym z roli recenzenta jako ekologa - recenzenta nierezygnującego z perspektywy i sądów wartościujących - tym razem z domieszką komponenty dydaktycznej: także dla polskich czytelników powieść Scuratiego (cała powstająca trylogia) to lektura obowiązkowa, poszerzająca nie tylko wiedzę o Włoszech, historii i kulturze Italii, lecz także naszą obywatelską świadomość.

\section{Bibliografia}

Andreini Alba (2017), Sconfinamenti. Le terre lontane di Cassola. Mostra su Cassola oltre frontiera. Montecarlo di Lucca, ex Chiesa della Misericordia 15 sett. - 5 nov. 2017. Grosseto, Polo espositivo culturale Le Clarisse 15 genn. - 5 mar. 2018, Effigi, Roma.

Benoit-Dusausoy Annick, Fontaine Guy, red. (2009), Literatura Europy.

Historia literatury europejskiej, przeł. Hanna Abramowicz i in., słowo/ obraz terytoria, Gdańsk.

Bereza Henryk (1968), Powieść romantyczna, „Trybuna Ludu”, nr 251, s. 6. Bernatowicz Grażyna (1990), Stosunki polsko-wtoskie 1944-1989, Polski

Instytut Spraw Międzynarodowych, Warszawa.

Biernacka-Licznar Katarzyna, Jamróz-Stolarska Elżbieta, Paprocka

Natalia (2018), Lilipucia rewolucja. Awangardowe wydawnictwa dla dzieci i młodzieży $w$ Polsce w latach 2000-2015, Wydawnictwo Naukowe i Edukacyjne Stowarzyszenia Bibliotekarzy Polskich, Warszawa.

Billip Witold (1960), Sympatyczne banaty, „Nowe Książki”, nr 14, s. $854-855$.

Corbel Marie-Anne (2009), Wtochy - Erri De Luca, w: Literatura Europy: Historia literatury europejskiej, red. Annick Benoit-Dusausoy, Guy 
Fontaine, przeł. Hanna Abramowicz i in., słowo/obraz terytoria, Gdańsk, s. 1027.

Eco Umberto (1995), Ur-Fascism, „The New York Review of Books” [dostęp: 20 sierpnia 2020], 22 czerwca, http://www.nybooks.com/ articles/1856.

Ferroni Giulio (2010), Scritture a perdere. La letteratura negli anni zero, Laterza, Bari.

Gołębiewski Łukasz i Kitrasiewicz Piotr (2005), Rynek książki w Polsce 1944-1989, Biblioteka Analiz, Warszawa.

Hamerliński Andrzej (1960), Opowiadania Alby De Céspedes, „Nowe Książki”, nr 19, s. 1183-1184.

Jaremko-Pytowska Zofia (1960), Gorzkie źródło, „Nowe Książki”, nr 8, s. $483-484$.

Kitrasiewicz Piotr, Gołębiewski Łukasza (2005), Rynek książki w Polsce 1944-1989, Biblioteka Analiz, Warszawa.

Kłos Anita (2009), Pogrzebana poezja. O recepcji twórczości Giuseppe Ungarettiego w Polsce, Wydawnictwo Uniwersytetu Jagiellońskiego, Kraków.

Kłos Anita (2018), Apologia kobiecego ducha. Sibilla Aleramo i jej związi $z$ polska kulturą literacka, Wydawnictwo umcs, Katowice.

Kralowa Halina (1968), Kłamstwo, czary i mitomania, „Nowe Książki”, nr 18 , s. 1248.

Miller-Klejsa Anna, Gałkowski Artur, red. (2012a), Od Boccaccia do Tabucchiego. Adaptacje literatury wtoskiej, Fundacja KINo, Warszawa.

Miller-Klejsa Anna, Gałkowski Artur, red. (2012b), Od Manzoniego do Maraini. Ekranizacje literatury włoskiej, Wydawnictwo Uniwersytetu Łódzkiego, Łódź.

Miller-Klejsa Anna (2013), Resistenza we wtoskim filmie fabularnym, Wydawnictwo Uniwersytetu Łódzkiego, Łódź.

Miller-Klejsa Anna, Woźniak Monika, red. (2014), Polsko-włoskie kontakty filmowe. Topika, koprodukcje, recepcja, Wydawnictwo Uniwersytetu Łódzkiego, Łódź.

Miller-Klejsa Anna (2016), Dekada otowiu na ekranie. Polityczny terroryzm lat 70. we wtoskim filmie fabularnym, Wydawnictwo Uniwersytetu Łódzkiego, Łódź.

Miller-Klejsa Anna, Dąbrowska Diana, red. (2018), Kino włoskie po 1980 roku, Wydawnictwo Uniwersytetu Łódzkiego, Łódź.

Misiewicz Katarzyna, Serkowska Hanna (2016), Tutto (si) è globalizzato? Sulla letteratura italiana nella Polonia dopo la caduta del muro, „Narrativa Nuova Serie”, nr 38, s. 89-101. 
Miszalska Jadwiga, Gurgul Monika, Surma-Gawłowska Monika, Woźniak Monika (2007), Od Dantego do Fo. Wtoska poezja i dramat $w$ Polsce (od XVI do XXI wieku), Collegium Columbinum, Kraków.

Miszalska Jadwiga, Gurgul Monika, Surma-Gawłowska Monika,

Woźniak Monika (2011), Od Boccaccia do Eco: włoska proza narracyjna $w$ Polsce (od XVI do XXI wieku), Collegium Columbinum, Kraków.

Niecikowski Jerzy, Sadkowski Wacław (1973), Glosa do artykułów Stefana Morawskiego, „Literatura na Świecie”, nr 8-9, s. 738-744.

Pogońska-Baranowska Aleksandra (w druku), Cassola in Polonia. Rachid Chebab Milena (2016), Skąd się biorą bestsellery, „Książki.

Magazyn do czytania”, nr 2, s. 15-18.

Rowiński Cezary (1960), Wyspa Artura, „Nowa Kultura”, nr 26, s. 11. Stempowski Jerzy (1938), Petnomonictwa recenzenta, [dostęp: 15 lipca 2020], https: / tinyurl.com/y44gph7r, [pierwodruk: „Pióro” 1938, nr 1, s. 95-112].

Ślarzyńska Małgorzata (2017), Obraz literatury włoskiej w Polsce w latach 7o. i 8o. Na łamach „Literatury na Świecie”, Wydział Polonistyki Uniwersytetu Warszawskiego, Warszawa.

Hanna Serkowska

I'm a Reviewer, not a Police Officer. From the Perspective of a Reviewer of Contemporary Polish Translations of Italian Literature after 2000

The article is an overview of Polish translations of Italian literature published between 2000 and 2020 . The presentation aims to capture the characteristic phenomena of the domestic market of translations from Italian to Polish in times dominated by capitalism and the new media. The author contemplates the role of the reviewer/literary critic in these new conditions, and asks whether reviewers/literary critics can still drive the readers' choices and receptions, and shape their knowledge and awareness.

Keywords: Polish translation; Italian literature; reviewer; critic.

Hanna Serkowska - profesor, italianistka i komparatystka. Studiowała w Polsce i w Stanach Zjednoczonych. Od trzydziestu lat związana z Uniwersytetem Warszawskim. Ostatnio zajmuje się Health Humanities, zwłaszcza medycyną narracyjną i narracjami maladycznymi. 
